\title{
Actions and opinions of Brazilian farmers who shift to sugarcane-an interview-based assessment with discussion of implications for land-use change
}

\author{
A. Egeskog ${ }^{\mathrm{a}, *}$, A. Barretto ${ }^{\mathrm{b}}, \mathrm{G}$. Berndes ${ }^{\mathrm{a}}$, F. Freitas ${ }^{\mathrm{c}}$, M. Holmén ${ }^{\mathrm{d}}$, G. Sparovek $^{\mathrm{e}}$, J. Torén $^{\mathrm{f}}$ \\ a Division of Physical Resource Theory, Department of Energy and Environment, Chalmers University of Technology, SE-412 96 Göteborg, Sweden \\ ${ }^{\mathrm{b}}$ Brazilian Bioethanol Science and Technology Laboratory (CTBE), 13083-970, Campinas, Brazil \\ ${ }^{\mathrm{c}}$ Division of Land and Water Resources Engineering, Department of Sustainable development, Environmental science and Engineering, Royal Institute of \\ Technology, Teknikringen 76, SE-SE-100 44 Stockholm, Sweden \\ ${ }^{d}$ Division of Innovation Management, School of Business, Engineering and Science Halmstad University, SE-301 18 Halmstad, Sweden \\ e USP-Esalq- University of São Paulo Av. Pádua Dias 11, Piracicaba-SP 13.418-900, Brazil \\ f SP Technical Research Institute of Sweden, Department of Energy and Bioeconomy, Eklandagatan 86, SE-41261 Göteborg, Sweden
}

\section{A R T I C L E I N F O}

\section{Article history:}

Received 15 December 2015

Received in revised form 27 May 2016

Accepted 16 June 2016

\section{Keywords:}

Brazil

Pasture intensification

iLUC policy

Deforestation

Beef

Rural farmers

\begin{abstract}
A B S T R A C T
Sugarcane ethanol systems can deliver large greenhouse gas emissions savings if emissions associated with land-use change are kept low. This qualitative study documents and analyzes actions and opinions among Brazilian farmers who shift to sugarcane production. Semi-structured interviews were held with 28 actors associated with sugarcane production in three different regions: one traditional sugarcane region and two regions where sugarcane is currently expanding. Most farmers considered sugarcane a land diversification option with relatively low economic risk, although higher risk than their previous land use. Beef production was considered a low-risk option, but less profitable than sugarcane. In conjunction with converting part of their land to sugarcane, most farmers maintained and further intensified their previous agricultural activity, often beef production. Several farmers invested in expanded production in other regions with relatively low land prices. Very few farmers in the expansion regions shifted all their land from the former, less profitable, use to sugarcane. Very few farmers in this study had deforested any land in connection with changes made when shifting to sugarcane. The respondents understand "environmental friendliness" as compliance with the relevant legislation, especially the Brazilian Forest Act, which is also a requirement for delivering sugarcane to the mills. Indirect land-use change is not a concern for the interviewed farmers, and conversion of forests and other native vegetation into sugarcane plantations is uncontroversial if legal. We derive hypotheses regarding farmers' actions and opinions from our results. These hypotheses aim to contribute to better understanding of what takes place in conjunction with expansion of sugarcane and can, when tested further, be of use in developing, e.g., policies for iLUC-free biofuel production.
\end{abstract}

(c) 2016 Elsevier Ltd. All rights reserved.

\section{Background}

Many studies have found that, when excluding indirect land-use change (iLUC), production and use of Brazilian sugarcane ethanol causes less greenhouse gas (GHG) emissions than gasoline (Egeskog et al., 2014; Galdos et al., 2013; Macedo et al., 2008). Studies have also investigated whether deployment of sugarcane ethanol in Brazil causes any significant GHG emissions due to iLUC. The

\footnotetext{
* Corresponding author.

E-mail addresses: andrea.egeskog@chalmers.se, egeskog.andrea@gmail.com (A. Egeskog).
}

results of these studies vary (Fig. 1), which is to be expected since different methods, models, and databases are used. When compared to the initial estimates of iLUC emissions in 2008, subsequent estimates are lower as models have been updated to consider improved efficiencies in feedstock production, decreasing deforestation rates, and increasingly stringent regulation of agricultural practices (Fig. 1), although large uncertainties remain (Verstegen et al., 2015).

California's Low Carbon Fuel Standard and the U.S. Renewable Fuel Standard include iLUC factors in calculations of biofuel GHG intensity (California Air Resource Board, 2009; USEPA, 2010). In the European Union (EU), iLUC factors are not included in 


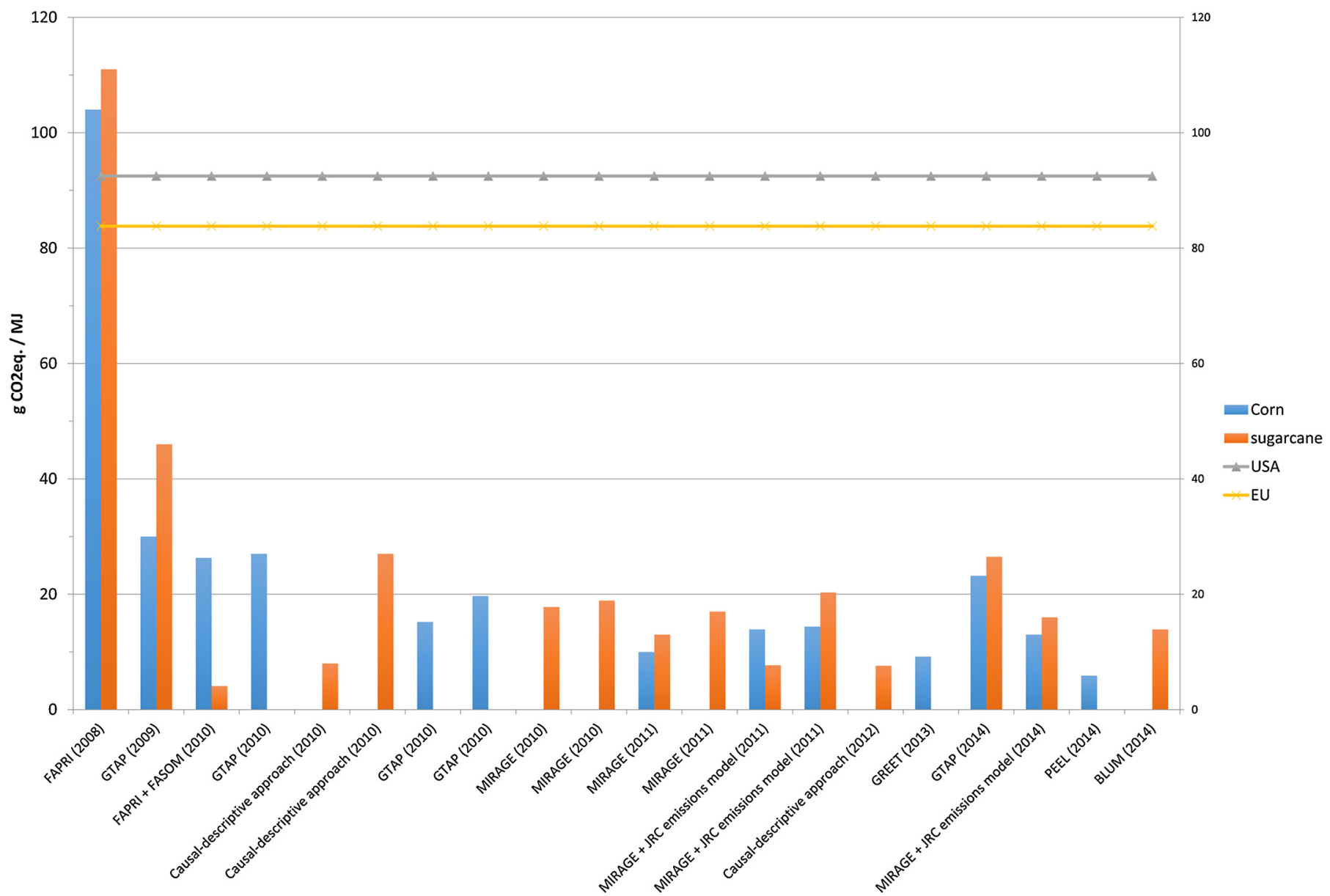

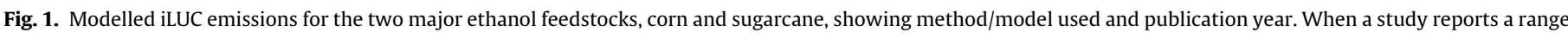

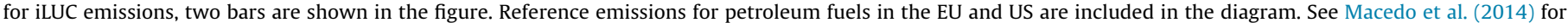
original sources.

GHG emissions for biofuels, but fuel suppliers and the European Commission regularly report on emissions deriving from iLUC (European Parliament Legislative, 2015). Using variable iLUC factors to reflect that different biofuel options may be associated with different iLUC risk levels is problematic in policy formulation due to the large uncertainties associated with quantifying iLUC (Broch et al., 2013; Leal et al., 2013). On the other hand, a policy with fixed iLUC factors does not incentivize individual actors to lower the iLUC risk associated with their production.

Schemes for identifying and promoting biofuels judged to have low risk of causing iLUC have been proposed (ABC, 2012; RSB, 2015). Brazil has created a national Low-Carbon Agriculture program ( $A B C$, 2012) in order to reduce GHG emissions connected to agricultural production and LUC. This program provides annual subsidized loans aimed at increasing agricultural productivity while reducing associated GHG emissions and supporting forest restoration by, for instance, constraining the land area occupied by extensive cattle ranching. Brazil is also aiming to reduce direct deforestation, an action which is unlikely to prevent large scale sugarcane expansion (Filho and Horridge, 2014). One proposed biofuel option with low risk of iLUC emissions is ethanol produced from sugarcane cultivated on pastures that become available because of intensified cattle production (Field et al., 2008; Francis et al., 2005; Embassy of Brazil, 2010; Garg et al., 2011; Lapola et al., 2010; President of the Republic of Brazil, 2008). Waste and organic residues that have no alternative uses are also considered low-risk, along with various approaches to improving land and resource use efficiency, such as (i) using marginal and/or degraded land (Field et al., 2008; Francis et al., 2005; Garg et al., 2011); (ii) integrating biofuel feedstock production into existing cultivation systems through multi-cropping schemes (Gesch and Archer, 2013; Heggenstaller et al., 2008; Langeveld et al., 2014); (iii) modifying crop rotations by reducing fallow periods and introducing land uses that provide biofuel feedstocks while maintaining soil quality and reducing environmental impacts associated with agricultural land use (Berndes et al., 2008; Dale et al., 2011); and (iv) integrating biofuel and livestock production systems in different ways, often based on using byproducts from biofuel conversion as animal feed (Dale et al., 2010; Egeskog et al., 2011; Sparovek et al., 2007).

The scopes of the schemes-applications, geographical scale, and number of actors involved-vary, but they share the premise that actions associated with establishing biofuel production should guarantee that the biofuels produced are essentially "iLUC-free". For example, farmers who invest in a project with specific actions to boost yield levels beyond what can otherwise be expected can be certified as providing feedstock for iLUC-free biofuels. The certified biofuel volumes would be determined by the amount of biofuel feedstock that can be made available thanks to the additional yield increase. The assumption is that since the farmers do not reduce their food production in order to supply biofuel feedstock there is no need for additional food production elsewhere to compensate for reduced food output. This reasoning reflects the mainstream narrative on iLUC, which captures the mechanisms considered in the equilibrium models used to quantify iLUC, i.e., farmers who cultivate biofuel crops influence land use outside the project boundary through their influence on food prices: lower 


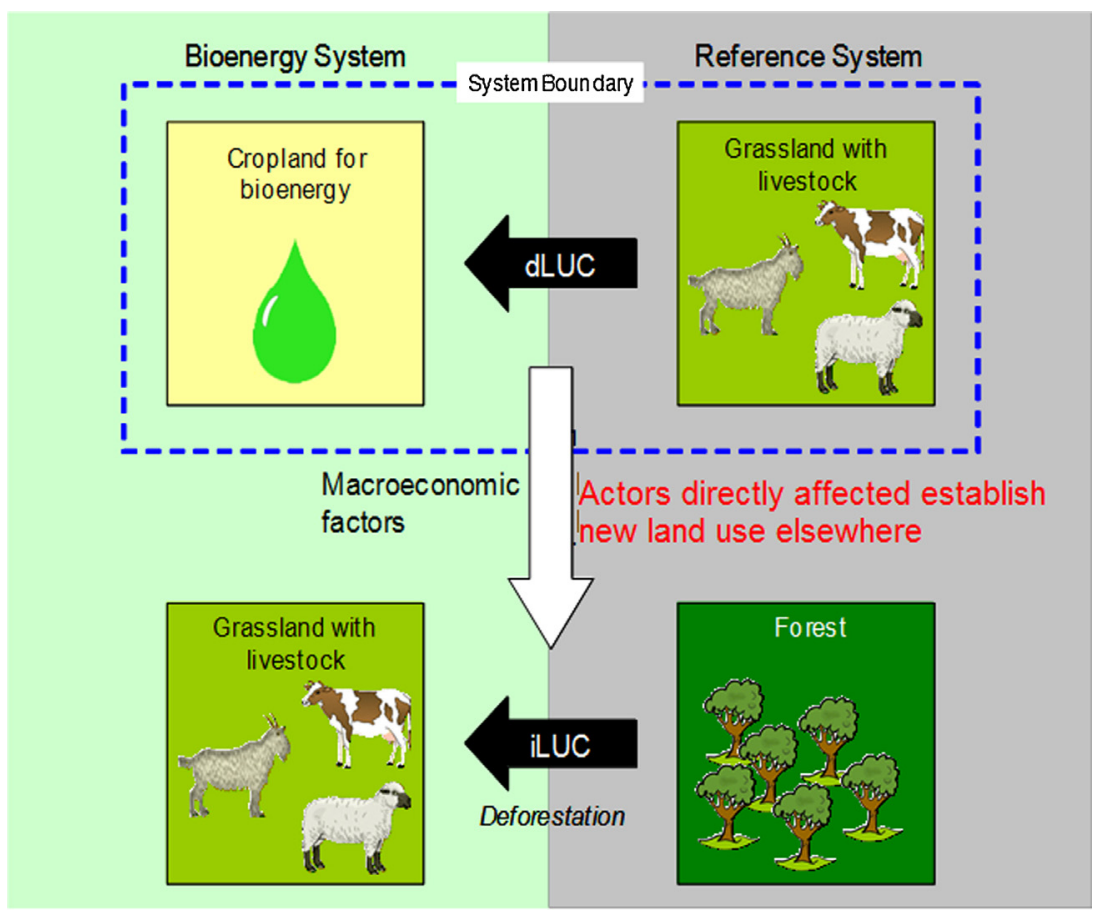

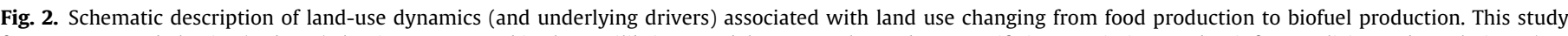

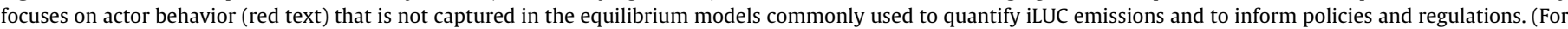
interpretation of the references to colour in this figure legend, the reader is referred to the web version of this article.)

production for the food markets (due to farmers' shift to biofuel crops) induces increased food commodity prices, which in turn affect food consumption, food industry operations, and also stimulate other farmers to increase their food commodity production, possibly causing LUC. Farmers who start cultivating crops for iLUCfree biofuels may also extend their own agriculture area. Such LUC may occur within the system boundaries defined for the project if it is part of the approach to produce iLUC-free biofuels; e.g., farmers may start cultivating feed crops to support increased productivity in meat and dairy production, which in turn releases pasture lands for biofuel feedstock cultivation. But if not closely associated with the iLUC-free production, the LUC may instead occur outside the project's system boundaries and therefore not be considered (Fig. 2).

One perspective on this is that farmers' actions outside the project's system boundary are part of the existing agriculture sector, which is not affected by the iLUC-free biofuel production as long as this does not cause reduced food production within the project's system boundary. Another perspective is that if many of the farmers who start cultivating crops for iLUC-free biofuels also engage in other activities known to be associated with LUC, such as beef production in frontier regions, then there is a risk that the schemes will not deliver as intended due to that they provide means and motivations for the farmers to increase their investment in such activities. In fact, if biofuel production certified as iLUC-free is more profitable than non-certified production, the schemes might even enhance LUC if the higher profits are invested in new agriculture land in frontier regions. Certified iLUC-free biofuels may then become produced without fulfilling the purpose to avoid negative LUC effects.

The literature investigating the relevant actions and motivations by farmers who start producing sugarcane is limited. Peres (2003), identified the main reasons farmers lease their land to sugarcane producers or to sugarcane mills. The most common motivations were connected with family matters or the economics of smallscale sugarcane production. The majority of the interviewed small landowners opted to lease their land instead of selling it due to the financial benefits of keeping the property and the value the farm has for the family. Novo et al. (2010), report that farmers engaged with milk production were motivated by elevated land prices and the higher payments offered by the sugarcane/ethanol industry. Novo et al. (2012), studied dairy farmers in a sugarcane expansion region in São Paulo (SP). They found that labor availability, household resilience, opportunities associated with diversification, and technology introduction (e.g., milking pit; milk refrigerator) are important motivators for continued dairy farming in lieu of engaging with sugarcane. All farmers interviewed in the abovecited studies were small holders. No study was found to have dealt with large landowners' views and actions when facing sugarcane production as an emerging option, especially when a sugarcane ethanol factory is planned or set up nearby.

This paper reports results from a qualitative study that documents and analyzes actions and opinions among Brazilian landowners and farm managers who have shifted fully or partially from pasture-based beef or milk production to sugarcane production or to leasing land to sugarcane producers. The focus is on events that take place after sugarcane ethanol factories have been established in the relevant regions. Special attention is placed on decisions and actions pertaining to intensification ${ }^{3}$ of remaining land use once the land has been dedicated to sugarcane production. Noting that farmers' decisions can influence land use and LUC directly or indirectly in association with the shift to sugarcane, and that schemes promoting iLUC-free biofuels may not recognize some of the decision-making processes that determine whether biofuels are free from iLUC, this study aims to derive hypotheses from its own results, regarding farmers' actions and opinions

\footnotetext{
3 The term intensification refers to increases in yields of existing crops or in cattle density. Replacing soy with higher-yielding sugarcane is not designated intensification. Feedlot systems and added winter feed are considered intensive/intensified systems as is increased productivity on extensively used pastures.
} 

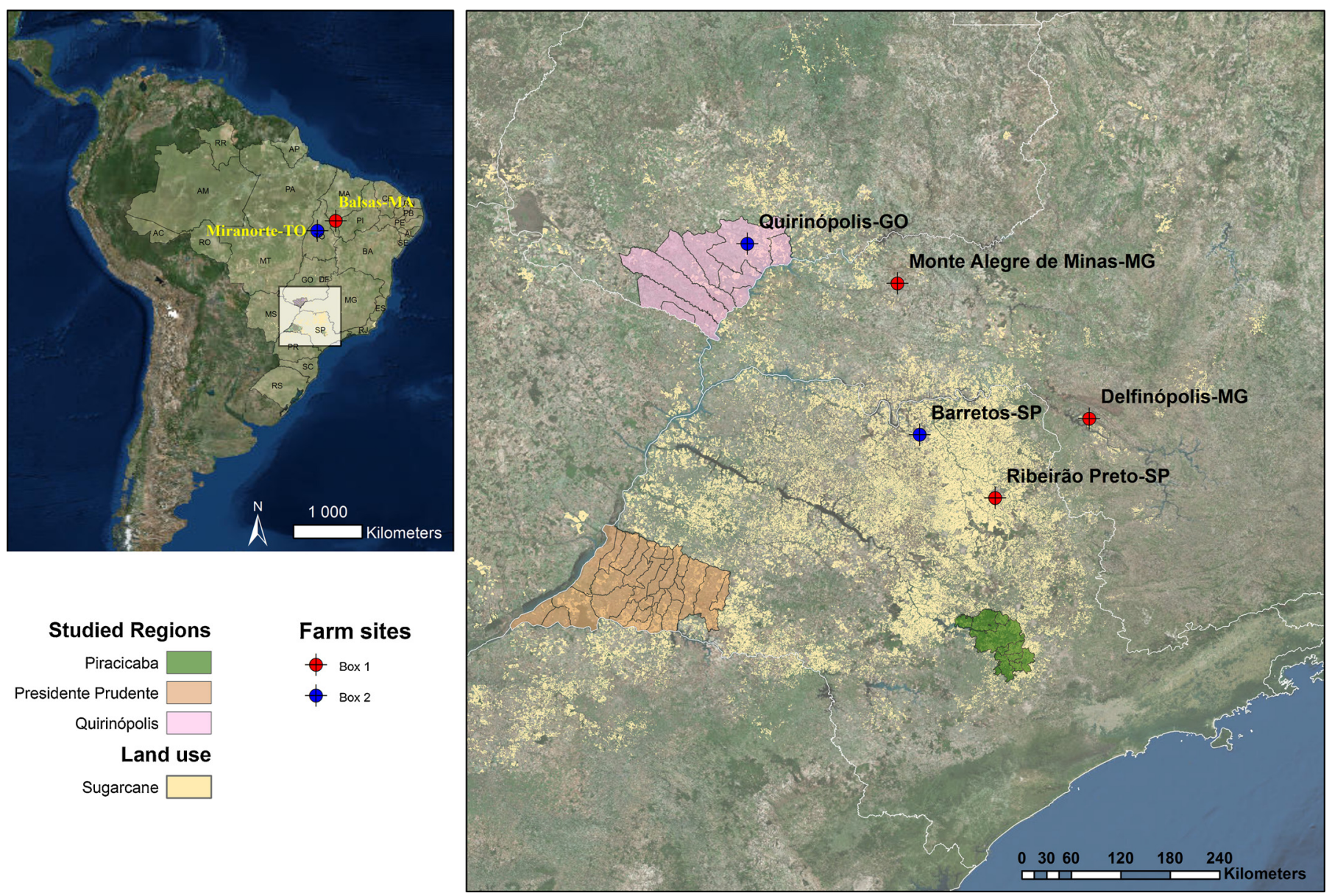

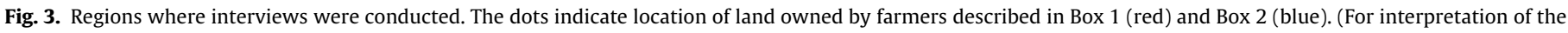
references to colour in this figure legend, the reader is referred to the web version of this article.)

in connection with a shift to sugarcane cultivation. When these hypotheses are tested further in a quantitative study, the results can inform development of new policies and sustainability certification systems, e.g., schemes for promoting iLUC-free biofuels. The hypotheses derived from the results and concluding discussion are meant to contribute to the understanding of the Brazilian agriculture sector as a complex system with multiple inter-linkages among actors as well as product markets (Fig. 3 ).

\section{Method and regions studied}

In March and April 2013, 28 semi-structured open-ended interviews (Kvale, 1997) were conducted in the Brazilian States of São Paolo (SP) and Goiás (GO). Eleven interviews were conducted in a traditional sugarcane region, Piracicaba (SP), and 17 interviews were conducted in regions where sugarcane is currently expanding, ten in Quirinópolis (GO) and seven in Presidente Prudente (SP), see Table 1 . Twenty interviewees were landowners, and fifteen of these had sugarcane on their land. Two interviewees managed land on behalf of landowners. Both these categories (land owners and managers) are referred to as "farmers. The remaining interviews were conducted with three agricultural consultants, two mill owners/representatives, and one researcher focusing on land-use issues, along with one representative of a large-scale family farm (only included in Box 1).

Farmers who are involved in sugarcane production are here referred to as "producers.P̈roducers receive payment based on the sugar content of the sugarcane. Twelve producers were inter- viewed, six in Piracicaba, five in Quirinópolis, and one in Presidente Prudente. Farmers who are not involved at all in the sugarcane production but lease their land to sugarcane producers are referred to as "lessors. T̈hey receive payment per unit land leased to sugarcane producers/mills. Five lessors were interviewed, three in Presidente Prudente, one in Piracicaba, and one in Quirinópolis. Noting the conclusion by Terci et al. (2007), that a distinction between producers and lessors is needed to understand sugarcane mill and farmer relationships, these two categories are analyzed separately when differences appear in the actions of producers and lessors. Farmers are also distinguished by region (see Table 1) when relevant.

In Quirinópolis, all interviews were arranged through the farmers' cooperative. In Presidente Prudente, a list with regional farmers was provided by the agriculture division of the municipality of Mirante do Paranapanema, and farmers were selected from this list. The remaining interviewees in Presidente Prudente were contacted based on recommendations during interviews. In Piracicaba, most interviewees were contacted through the sugarcane cooperative active in this region. According to the interviewees, almost all farmers in Quirinópolis and Piracicaba use the cooperatives services. The interviews were recorded, and when they were not conducted in English, native Brazilians, generally agronomy graduates, translated the Portuguese to English, partly during and partly after the interviews. Fig. 4 shows the type of activity that the 22 interviewed farmers engaged in at the time of the interviews.

The interviews focused on actions before, during, and after the change to sugarcane. If the interviewees had taken over a sugarcane farm (relevant in the traditional sugarcane region Piracicaba), 
Table 1

Interview regions.

Piracicaba (SP) - Traditional sugarcane region

The first mill was set up around 1850. At that time, agriculture in this region focused on coffee, cotton, silk, and beef. After 1975, the sugarcane sector, supported by the "Proalcool" government program, turned this region into one of the most important in the state for sugar and ethanol production. The area is hilly, so mechanical harvest is only used on about half the sugarcane fields.

Presidente Prudente (SP) - Expansion region

The first mill was set up in 1970; it was a small mill producing only ethanol. From 2007-2009, new modern mills producing both ethanol and sugar were set up in the region, and the old mills were shut down or modernized. The main agricultural activity in the region is extensive beef production. Many of the landowners live in other regions in the state and oversee management of this land at a distance. The area is flat, and almost all sugarcane is harvested mechanically.

Quirinópolis (GO) - Expansion region

The area has two mills; the first mill was set up in 2006 and the second in 2008. The main agricultural activity in the region is extensive beef production. In the 1970s, many farmers from SP and Minas Gerais (MG) came to this region to start beef production. More recently, farmers from the south have come to the region to start soy production. The area is flat, and almost all sugarcane is harvested mechanically.

Regional agricultural data

Crops $^{\mathrm{a}, \mathrm{b}}$ (ha, 2013)

of which sugarcane in 2013 (and in 2006)

Effective herd (heads of cattle) in 2013 (and in 2006) ${ }^{c}$

$\begin{array}{ll}\text { Piracicaba } & \text { Presidente Prudente } \\ 170,000 & 430,000 \\ 160,000(120,000) & 340,000(120,000) \\ 160,000(160,000) & 1,500,000(1,800,000)\end{array}$

a Source: IBGE SIDRA (2013).

b Permanent crops account for a very small share of the total cropland area.

c The most recent value for total pasture area is from 2006, so the "heads-of-cattle"-measure is used instead.

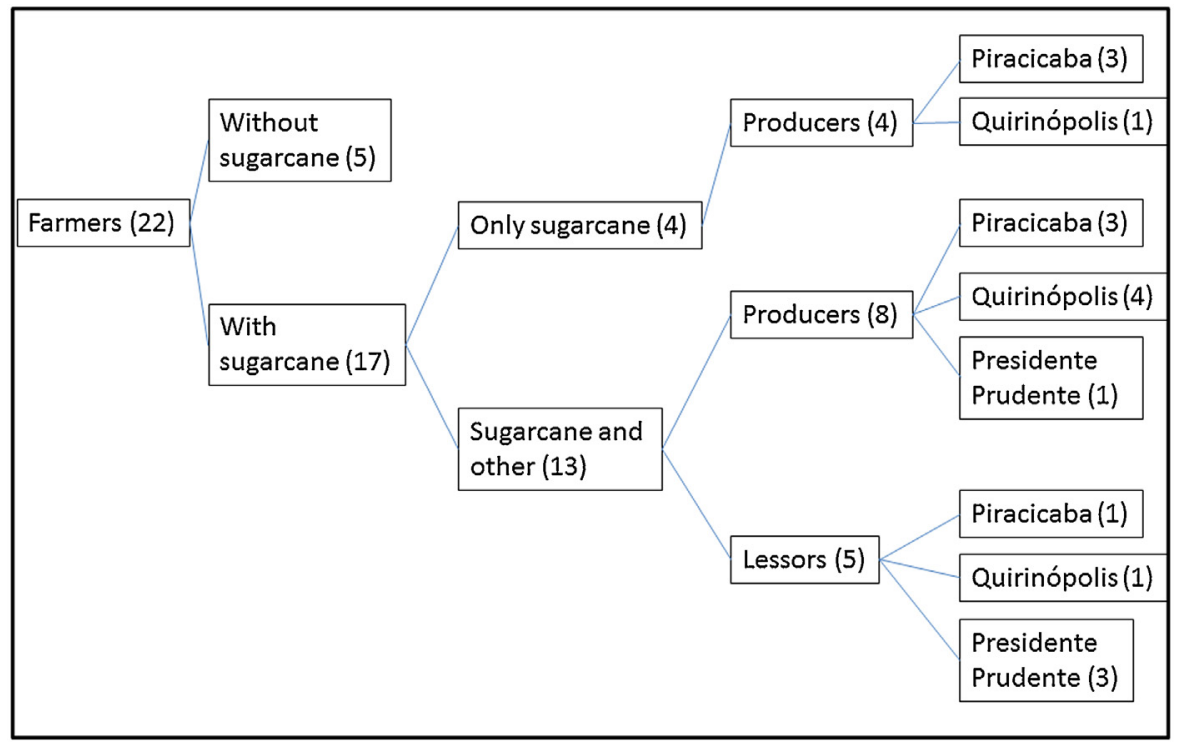

Fig. 4. Schematic description of the 22 interviewed farmers. The number of farmers in each category is given in parenthesis.

the focus was on actions associated with sugarcane production and other agricultural activities. Most interviews covered the following topics: farm history; changes in land use and farming activities; reasons for investments or disinvestments; environmental and economic concerns; opportunities; and farmers' networks. Interviews with the other actors complemented the farmer perspectives. The wide range of farm types covered--small and large farms, corporate farmers (or corporate farm groups, i.e., companies controlling large areas) and more traditional farmers who do things as they have always done and are reluctant to adopt new technologies, peasants (land owners living on their farm) and absentees (land owners not living at their farm)--provides a broad overview of factors that affect farmers' decisions.

The interviewee selection process was not randomized, and the number of interviews was not set beforehand. Rather, interviews in the different regions were made until we determined that additional interviews would not yield any new relevant information. Hypotheses regarding the farmers' actions and opinions were derived from the interviews. In 2013 when the interviews were conducted, some mills had applied for bankruptcy, and since then a deeper crisis has developed in the sector ${ }^{4}$ (UNICA, 2015). From late 2012 to late 2014, gasoline prices did not increase and stabilized at a value lower than expected by the market (Anon., 2016). This has negatively affected the ethanol price and thus the sugarcane industry. These effects had only started to surface at the time of the interviews. The conclusions and policy considerations presented below are applicable in the context presented in the background section. After the interviews took place, one of the mills in Quirinópolis started co-producing ethanol from sugarcane and corn, reducing exposure to fluctuations in sugarcane production.

\section{Results}

A majority of the farmers who started sugarcane production also continue their earlier agricultural activities to lower the financial risks. Previous activities are often intensified and sometimes moved to other locations. Even though many sugarcane mills filed for

\footnotetext{
4 Presently, 70 mills are in the process of filing for bankruptcy in addition to the more than 80 that have already done so in recent years (UNICA, 2015).
} 


\section{Box 1: Corporate farming run by a family.}

Information in this box is based on an interview with a representative of a large-scale family farm in Ribeirão Preto (RP), São Paulo. He is the executive manager of a family business that he runs since 1994, with his father, brother, and two sisters. The family business was established in 1948 by his grandfather who initially produced cotton, corn, and beef. In 1956, his grandfather started growing sugarcane. Between 1972 and 1995 the business expanded, and today the family owns two farms in RP, with a total area of 1625 ha. In 1995, just after the interviewee took over management of the business, the family decided to further scale up operations. Due to high land prices at this time, they decided to lease land, and today they lease almost 10,000 ha in RP and Minas Gerais. In 1999, more than $90 \%$ of their profit came from sugarcane, with the remaining from 20 other activities (including milk, beef, pork, fish, and crops). At that time, the family decided to focus on fewer crops, and today sugarcane in rotation with soy covers 5500 ha out of 11,500 ha, and soy in rotation with corn, sorghum, or grass covers the remaining 6000 ha. Sugarcane is still the largest contributor to their profits in RP.

In 1994, the interviewee along with his brother and father bought land at the frontier region of the northeastern Cerrado, in Maranhão (MA). The land was cleared, the infrastructure and soil quality were improved, and licenses for the property were obtained. As a result, the value of the land has more than tripled according to the farmer. Today they grow soy and corn in MA. Due to the dry climate, pasture is the only rotation option. Residues from the corn are used as feed in their feedlots. The interviewee suggested that one reason many farmers do not find feedlots attractive is that these farmers are beef producers and not crop producers. "You have to be a good grain producer to get good profits with feedlots," the farmer states. In MA, the family manages 13,000 ha, of which they own $80 \%$. The business in RP and Minas Gerais is kept separate from the business in MA. However, the farmer states that without money from the sugarcane business in RP, they would not have been able to buy additional land in other regions.

The family plans to further expand the business and either buy or lease more land. They will also further improve the crop and cattle systems. Purchasing more land is not a primary goal but may be considered if a good opportunity presents itself.

Land purchases are most profitable when the purchase price is very low and improvements can be done to increase the value of the land. In today's Brazil, this mostly applies to land still covered by natural vegetation located in areas with poor infrastructure, mainly Cerrado. Vegetation on the purchased land is cleared and soil quality and infrastructure improved. In Brazil this is called "negócio de terras." The family considers this a business in itself, and they use money from this process in their agricultural production.

bankruptcy in 2013 (UNICA, 2015), the interviewed farmers were positive about sugarcane cultivation. Most interviewees consider sugarcane to be higher-risk than their previous activities. Environmental compliance has increased among the farmers who have changed to sugarcane, and it was evident that the industry pushes strongly for compliance with the Forest Act. The results below focus on the 17 farmers engaged with sugarcane (Fig. 4).

In Quirinópolis, crop producers were the first to change to sugarcane (personal communication with employees at the sugarcane cooperative in the region, March 2013). The change is said to have occurred due to the soy crisis in Brazil, which coincided with the construction of the first mill in the region in 2006. Pasture farmers could not switch as easily due to their investments in fences, milking machines, etc. Many of the soy farmers who leased or sold their land to sugarcane producers are said to have stopped their own operations and moved to the city or moved their operations to other regions. In Presidente Prudente, most of the landowners who leased their land to sugarcane producers are said to have engaged in extensive cattle production previously. In Piracicaba, most interviewed farmers have cultivated sugarcane on their land for many generations, and it is their main agricultural activity. Since the farms have been divided among siblings for many generations, the farm sizes are generally small compared to in the expansion regions. Among the interviewees, crop production (other than sugarcane) is the most common agricultural alternative to sugarcane.

\subsection{Actions: displacement and intensification of beef production}

All interviewed farmers who started sugarcane operations (12 of 17) planted their sugarcane on former pastures. The farmers who did not plant sugarcane on pastures are all from Piracicaba and have all had sugarcane on their farms for at least three generations. Most (11 of 12) of the farmers who started sugarcane production also continued pasture production, either in the same region as the sugarcane plantations or elsewhere. Two farmers, one lessor from Presidente Prudente and one producer from Quirinópolis (see Box 2 ), stated that they bought new pastureland in other regions after they had planted sugarcane on their former pastures. One additional farmer did not yet have enough capital to buy new land but was hoping that the income from sugarcane would make it possible in the future. Farmers in the expansion regions commonly stated that they wanted to buy more land but that land prices were too high at the moment. Instead, these farmers increased production on their remaining pastures.

Almost all (9 of 11) who had pastures made investments to enhance land-use intensity or had already started such improvements before they engaged with sugarcane (two farmers). The most common way to intensify milk/beef production is to improve the quality of the pastures (e.g., by planting new grass species) and to increase the stocking rates. Income from sugarcane makes it possible for the farmers to invest in this type of intensification. However, farmers stated that intensification of beef production is not economically beneficial even though they actually intensified their production. An explanation for this could be that most farmers refer to feedlot systems as intensified beef production.

Most ( 5 of 7 ) of the farmers who started intensified beef production once they started with sugarcane produce beef in a different region than sugarcane. Land prices go up where sugarcane is established, making beef production less cost-competitive in these regions. Farmers therefore invest in beef production in other regions where land prices are lower. One producer from Quirinópolis intensified beef production in an area where he had cleared new land for pasture after starting sugarcane operations (see Box 2 ). The others who had beef production in other regions had bought already-cleared land (or did not clarify if and when they had cleared land).

\subsection{Opinions of the farmers}

\subsubsection{Farmers have a positive view of sugarcane}

In the expansion regions, all interviewed sugarcane farmers were positive about growing sugarcane. In Quirinópolis and Presidente Prudente, interviewees (both farmers and agricultural consultants) stated that farmers with a history in traditional sugarcane regions had decided that they would start with sugarcane as

\footnotetext{
1 His average for the last four years is 104 ton sugarcane/ha and he has fields that give 173 ton sugarcane/ha from the first harvest and 140 from the second.

2 This makes it possible to increase the number of animals from 1 to 5 animals per ha in 2-3 years. However, the increased productivity may make it profitable to fertilize the pastures, and then the yield of 5 animals per ha can be maintained.
} 


\section{Box 2: Sugarcane profits going to the beef sector}

Information in this box is based on an interview with a largescale family farmer living in Quirinópolis (GO). He owns two farms and also manages a third farm (in Quirinópolis) owned by his wife. He is the fourth generation of a well-known beef production family focused on breeding beef cattle.

The farmer has run the farm in Quirinópolis since 1995 when his wife inherited it. The farm has 400 ha of legal reserves in the Atlantic Forest Biome. He often wishes he had cleared it when he took over management in 1995 since he is now missing out on approximately USD 200,000 per year in potential profits from this area. Had he cleared the land in 1995, he would have been able to buy much cheaper land now, in another location for his legal reserve. If the legal reserve had consisted of Cerrado he would be allowed to cut it, while Atlantic rainforest is now legally protected. However, he also appreciates that the legal reserve on his farm supports diverse wildlife.

Sugarcane was not considered an option until the start-up of a sugarcane mill construction only $2 \mathrm{~km}$ from the farm, when the mill owner contacted the farmer. Before deciding to engage with sugarcane, the farmer discussed the matter with friends who are sugarcane producers and visited sites. Since the cost of reverting back from sugarcane to beef is high, he initially planted sugarcane on a small share of his pastures to gain experience before scaling up. In 2013, 870 ha of pasture land was planted with sugarcane and the remaining 30 ha was to be planted in 2014. The only part of the operations that is not managed in-house is the insecticide spraying by air. The fields are irrigated and yields are judged by the farmer to be the highest in the area and among the highest in the country. ${ }^{1}$ The farmer is active in the sugarcane producer cooperative in the region, and many farmers visit the farm to learn more about efficient sugarcane production.

The second farm, located in Miranorte, Tocantins (TO), consists of 4500 ha pasture land used for beef production. The farm was bought in $\mathbf{2 0 0 2}$ with money received when a farm in Jussara (MG), was sold. In order to intensify his production in Miranorte, the farmer plans to improve pasture quality by planting corn for $4-5$ years before moving beef onto the land. ${ }^{2}$ The current beef production is not sufficiently profitable to enable fertilization of the pastures and still operate at a profit. In 2010, the farmer inherited a beef farm of 580 ha, located in Barettos (SP), which is now used for sugarcane production managed by the local mill. In 2013, he sold 193 ha in Barretos for BRL 8 million and bought an additional 1142 ha in connection to the Miranorte (TO) farm for BRL 3 million. He plans to use part of the remaining BRL 5 million to improve his sugarcane production in Quirinópolis but will mainly invest in TO, buying new machines, employing more people, increasing the number of cattle, and starting with corn production at a small scale to learn, as he did earlier with his sugarcane. The plan is to increase grain production to $70 \%$ of the allowed area in TO since that proportion of the property is flat and therefore suitable for crop production. The remaining $30 \%$ will be used for cattle production. The farmer estimates that the 1142 ha in TO will give the same annual income as the 193 ha area did in Barretos and will have a much greater potential for growth. He is "...looking for the income, not the location" when buying land. The engagement with sugarcane is said to provide capacity for buying land and improving production, which would not be possible if all land were dedicated to cattle production.

soon as they got a good offer from a trusted company, even before plans to build mills in the regions had been announced. Those from regions/families without a sugarcane heritage waited some time to see whether those who shifted early prospered. Many farmers also highlight the contribution of the sugarcane mills in the regions; the mills boost the local economies by driving up wages and increasing the general income level for the local population. In the traditional region Piracicaba, farmers were also positive towards sugarcane.

Another reason why the producers hold sugarcane in such positive regard is the associated payment model. Based on the total amount of sugar delivered annually to all mills (not only your own mill) and the value that all sugar and ethanol products are sold for, all farmers are paid the same amount per $\mathrm{kg}$ sugar delivered. When farmers harvest in July, they are paid $80 \%$ of the assumed total payment. If the payment index, ATR, ${ }^{5}$ remains the same as when the farmers delivered the harvest to the mill, they will receive the additional $20 \%$ of the payment in equal shares from January to April. If the ATR is higher than when the harvest was sold, they get a larger payment than $20 \%$ and vice versa. Even though the farmers consider this payment model fair, they feel that the value of the electricity from the bagasse should be included when calculating the ATR value. If profits from bagasse were included, producers would be less exposed to fluctuations on the fuel market.

\subsubsection{The appeal of producing sugarcane vs. leasing land to producers/mills depends on context}

In general, the reason given for producing sugarcane rather than leasing land to producers was that the former yields a higher profit. Based on data from the interviewees, profits from producing sugarcane are estimated to be roughly twice as high as from leasing the land to producers (Table 2).

Stated reasons for leasing land to sugarcane producers vary across the three regions. In Presidente Prudente, many landowners are said to obtain their main income from non-agricultural businesses and lease their land to growers because that is the most profitable option that they could manage time-wise. Leasing is viewed as an income opportunity free of entrepreneurial risk and is in some instances a way to avoid family disagreements over inheritance, since payment is immediate and can be divided among inheritors without delay. An additional reason stated among farmers is that some mills do not buy sugarcane from producers; they lease land and produce all sugarcane themselves. However, a mill representative in Presidente Prudente stated that producers would be preferred but that there were barriers associated with insufficient knowledge about sugarcane production among the farmers at the moment. Farmers in Presidente Prudente have specialized in livestock production and hence lack the infrastructure associated with crop production (including machinery and know how).

In Quirinópolis, those with small properties are said to lease their land to growers due to insufficient capital for investment in machinery for sugarcane production. Had they been producers, the cost of renting all the equipment and services needed would reduce the profit to roughly the same level as from leasing. However, the only interviewee leasing land to growers in Quirinópolis is not representative of this. He is a large-scale beef producer, living in the city of São Paulo, whose main income comes from non-agricultural businesses.

In Piracicaba (traditional region), most of the farmers are producers, but according to a representative from the sugarcane cooperative in Piracicaba many in the region are considering leasing their land to growers/mills instead. Leasing is considered a safer option and almost as profitable in the region. The banning of burning before harvest is said to be the reason for the reduced profitability, especially for small-scale producers that do not own

\footnotetext{
5 The ATR index is based on total value of all sugar products and ethanol sold annually. On arrival at the mill, each truck with sugarcane is weighed, and then a sample of sugarcane from each truck is collected to calculate the sugar content in the sugarcane. All the sugarcane mills report to UNICA (representing the industry) and ORPLANA (representing the producers), and together they come up with a formula to calculate the total sugar delivered and use that to determine a price for the sugarcane to be paid to all producers.
} 
Table 2

Profits from leasing land to producers and from producing sugarcane, beef, and milk (based on data from the interviews).

\begin{tabular}{|c|c|}
\hline Profit from: & BRL/ha/year (no. of farmers; source) \\
\hline Sugarcane production & $1500-2000$ ( 3 ; farmers $) 1100$ ( 1 ; farmer $) 1000$ ( 1 ; farmer, not yet a cane producer $)$ \\
\hline Leasing land to sugarcane growers & $600-800$ (6; farmers) \\
\hline Beef production (about 3 animals per ha) & 300 (2; farmers) \\
\hline Beef production in the Center South ( 1 animal per ha, on average) & 75 (0; Agroconsult (2014)) \\
\hline Milk production in Quirinópolis (average) & 450 ( 1 ; agricultural consultant) \\
\hline Intense milk production in Piracicaba & 3000 (2; farmers) \\
\hline
\end{tabular}

a harvester. A regional law passed in July 2012 (Ministerio Público, 2012) makes harvest with burning illegal for all types of land in the region. Before that law, at least $40 \%$ of all sugarcane in Piracicaba was burned before harvest. Interviewees in Piracicaba stated that the cost for mechanical harvest and manual harvest without pre-burning is roughly $30 \%$ higher than for manual harvest with pre-burning, thus the small producers deem the upfront costs prohibitively expensive. Many small producers therefore consider becoming lessors instead of producers.

\subsubsection{Farmers diversify production to lower risk and most who engage with sugarcane also continue their earlier activities}

A majority (13 of 17) of the farmers who engaged with sugarcane are also engaged in other agricultural activities (Fig. 4). Seven farmers, all from the expansion regions, produced beef; two farmers produced milk; one farmer produced grains, and three farmers produced both grains and beef. Most ( 9 of 13) of the farmers who had more than one agricultural activity came from an expansion region, and all of them had pastures. In the traditional region Piracicaba, grain production was a more common complementary activity to sugarcane.

Farmers who engaged in both sugarcane and other agricultural activities commonly wanted to diversify their production to spread risk and secure income. Sugarcane production most often provides one payment per year, while milk production provides a monthly income, and beef can be sold at any time. Sugarcane is considered less safe due to dependency on one specific mill that can face economic challenges or even go bankrupt. Beef and grains are less restricting than sugarcane since these products can be sold to whomever the farmer prefers. Both lessors and producers in the expansion regions consider sugarcane more financially risky than beef or milk production, but still prefer it due to the much higher profitability. Farmers in the traditional sugarcane region consider sugarcane to be the safest agricultural investment. The interviewees report that farmers spread their risks through investments in related businesses, such as sugarcane transportation from fields to mills, and in properties. Two of the three farmers from Piracicaba who only produce sugarcane had income from other non-agricultural activities. Two farmers from Quirinópolis said they diversified because they come from traditional beef families and therefore wanted to keep working with animals.

All four of the farmers who only had sugarcane on their lands are producers. Three of them are farmers from Piracicaba and had produced sugarcane for generations. Two of them produced beef and milk earlier but stopped due to difficulties in finding skilled labor. One sugarcane producer from Quirinópolis did not have enough space for more than one activity on his property. He grew sugarcane as it was the most profitable option but would have preferred beef production as it provides better scenery.

Even though intense milk production could be twice as profitable as sugarcane (Table 2), only three of the 22 interviewed farmers considered this an option for their farm. They explained that it is difficult to find the skilled labor required for milk production. One farmer in Quirinópolis had even had a prized milking farm but had to close it for this reason. Even if income in urban areas is not better than in rural areas, leisure time, and other quality-of-life factors are perceived to be better in urban than in rural areas (Novo et al., 2010).

The increasing land prices in sugarcane regions affected farmers' decisions to intensify existing pasture production or instead expand their properties. The increased land price also made some of the farmers buy additional land in the frontier regions where land prices were more competitive for beef production.

Three of the farmers own several rural properties located in different regions. These farmers are more business-oriented than the others (see also Boxes 1 and 2). They use their entire farmland in the sugarcane region for sugarcane production, since this activity is more profitable than beef. The profits from sugarcane are used to buy land or to intensify other production at their farms located in other regions. This example of money transfer between sectors can be challenging to capture in general equilibrium models.

According to the interviews, perceived risk and managerial difficulties led most farmers to not exclusively prioritize the most profitable grain/pasture use at any point in time. They may have favoured their prior, less profitable, activity due to, e.g., difficulties in finding skilled labor for a more profitable option, aesthetic preferences regarding landscape scenery, the effort involved in learning about a new area of agriculture, traditional views as to what it is to be a farmer, or a preference for working with animals. At traditionally run farms, production sometimes doesn't change until a new generation takes over, even though change would have been economically rational before that (see Boxes 1 and 2 ). In such cases, a shift to sugarcane may be delayed compared to if the decision to switch were based solely on a straightforward cost-benefit analysis.

\subsubsection{Those who start with sugarcane continue unless conditions change drastically}

Agricultural consultants in the two expansion regions state that all farmers in their regions who have engaged with sugarcane have continued with this activity. The explanation, besides higher profits from sugarcane compared to former activities, is the high cost of rebuilding former infrastructure (e.g., building fences for beef and milk production). In the traditional region, none of the interviewed farmers had stopped cultivating sugarcane, but since burning before harvest was recently banned and only $60 \%$ of the sugarcane area was suitable for mechanical harvest, it is possible that farmers will switch to other activities in the near future.

\subsection{Farmers follow the environmental laws but do not go beyond legal requirements}

All interviewed farmers stated that it was important for them to be environmentally friendly, by which they meant following the Brazilian Forest Act (Law, 2012). The farmers did not consider conversion of forests and other native vegetation to agricultural land as controversial if it was legal. The sugarcane industry appears to be strongly oriented towards full compliance with land-use legislation in Brazil. The industry's demand for compliance with the law has most likely affected farmers' opinions regarding what is environmentally friendly.

To comply with the Forest Act farmers must keep a certain amount of forest in the same biome (and often also same state) as 
their agricultural area (Law, 2012). The size of the protected area depends on the size and location of the farm. All but one of the interviewed farmers in Quirinópolis maintain their legal reserve in another location, due to the lower land prices further away from the sugarcane region. The mills in Quirinópolis do not sign contracts with farmers with insufficient legal reserves.

Most farmers in Presidente Prudente and Piracicaba own land that was deforested before 1960 and thus do not have to increase their legal reserves even if these are below the required shares stated in the Forest Act. ${ }^{6}$ In Presidente Prudente (expansion region), two of the five farmers have legal reserves on their farms. The remaining three do not have legal reserves and stated that since the Forest Act is still unclear, they are waiting for clarification before they take action, if at all needed. In Piracicaba (traditional region), all interviewed farmers were waiting for clarification of the Forest Act. Post-interview analysis suggests that farmers were not waiting for clarification from federal or state authorities but from the respective sugarcane mills. The clarification would pertain to requirements for legal reserves as well as permanent protection areas around water bodies on their property.

None of the interviewed farmers were aware of the international discourse on assigning an iLUC factor to Brazilian ethanol, though some had followed the debate about sugarcane leading to deforestation. The mills' requirement that farmers follow the Forest Act has led to full compliance among the interviewed farmers in Quirinópolis. Based on the interviews we find that (i) incentives and regulations covering activities that today count as legal deforestation are likely needed for deforestation to stop, and (ii) if mills impose compliance with other laws or certificates (e.g., certified ethanol programs) this will probably also lead to full compliance among the farmers.

\section{Discussion and hypotheses}

The farmer's actions and opinions can be understood in relation to incentives and decision structures emerging from context conditions that can vary significantly. Based on analyzes of the results from the interviews we derive a number of hypotheses. Many of these concern farm structure and farmers' actions and opinions in relation to new opportunities, innovation, and risks. We hypothesize that i) farmers generally diversify production to lower the financial risk and engagement in new activities need not mean that previous activities end; ii) both corporate and traditional farmers keep and intensify their cattle production; iii) corporate farmers tend to plant all pasture land with sugarcane and move their cattle production elsewhere, while traditional farmers convert only part of their pastures to sugarcane; (iv) farmers in sugarcane regions are positive towards sugarcane farming on their land, and farmers who engage with sugarcane can be expected to continue their engagement as long as conditions do not change drastically for the worse. Specifically concerning family-run farms, we further hypothesize that (v) inter-generational considerations delay actions.

We noted additional region-specific factors that appear to influence incentives and decision structures associated with sugarcane and we hypothesize that (vi) attractiveness of producing sugarcane vs. leasing land to other producers depends on factors such as time available for management, access to skilled workers and machines, and level of crop cultivation knowledge; and that (vii) farmers engaged with sugarcane may experience greater pressure

\footnotetext{
${ }^{6}$ According to the Brazilian Forest Act, if a property was deforested before 1960 when the first set of standards regarding legal reserves was proclaimed, reforestation is not required (Agroconsult, 2014). However, the forest now standing must be kept, and permanent protection areas around all water on the property have to be fulfilled.
}

to comply with legislation than other farmers, due to the sugarcane ethanol industry's orientation towards full compliance with landuse legislation. Thus, regional and state-level legislation becomes important.

The above hypotheses imply that since farmers can make very different decisions when engaging with sugarcane, the extent, location, and timing of the LUCs that are directly and indirectly associated with the shift to sugarcane will vary. LUC consequences of planting sugarcane depend on the extent to which intensification of the former production on the remaining pastures compensate for the pasture area reduction. Further, corporate farmers who plant sugarcane on all their pasture land may continue with meat/dairy production but in new locations. When this relocation involves establishment of new pastures, the sugarcane planting can be said to cause iLUC. However, if the farmers acquire and intensify existing meat/dairy production, this may reduce the iLUC, and the net effect may even be land-saving, i.e., "negative iLUC."

This variation in possible LUC outcomes makes it challenging to design schemes for promoting iLUC-free biofuels. One might argue that the purpose of such schemes is to address iLUC caused by effects of biofuel promotion on food markets. But, as noted earlier, if those farmers that engage with iLUC-free biofuels in fact also engage in activities causing LUC elsewhere, then the purpose of the schemes (to avoid negative LUC effects) may not be fulfilled since they do not address all relevant actions taken by the farmers involved. Almost half of the farmers in this study who had both sugarcane and beef also had beef production in a region other than the one where they produced sugarcane. However, as noted above, it is also possible that the schemes contribute to "negative iLUC."

The issue of additionality presents another challenge. According to, e.g., van de Staaij et al. (2012), most interviewed farmers in the expansion regions could qualify as producers of feedstock for the production of iLUC-free biofuels, since sugarcane planting occurred on pastures with low productivity, and investments to improve yields and efficiencies of remaining meat/dairy production were common. However, this behavior was not due to the existence of schemes to promote iLUC-free biofuels, and if such schemes were established it would be difficult to judge whether they induce land-saving investments that are additional to what would otherwise occur.

The spatial scale of schemes also matters. Consider, for example, the farmer presented in Box 2, who has helped increase total sugarcane productivity in the Quirinópolis region, which means that less pasture land needs to be planted with sugarcane to support a given volume of ethanol production. A scheme to promote iLUCfree biofuels that uses a regional scale for evaluation would certify this farmer. However, since he has moved his whole beef production to another area, he might not be certified if the criteria were set at the level of individual farm businesses. System boundaries and regional vs. individual assessments affect outcomes to a large extent and make control of all impacts difficult to assess.

Schemes promoting iLUC-free biofuels may provide important room for innovation and spur development of better-performing systems. In the longer term, this may spill over to conventional biofuel production as well as to agricultural production in general. Assuming that the production of iLUC-free biofuels will represent a very small part of total agricultural production (today sugarcane is cultivated on less than $4 \%$ of Brazils total agricultural area (crops and pastures) (IBGE SIDRA, 2013), such spill-over effects may well be the most important contribution of these schemes to mitigating undesirable LUC associated with biofuels and agricultural development as a whole. From this perspective, it is important to ensure that promotion of iLUC-free biofuels through cultivation of marginal/degraded lands does not promote inferior production systems whose only real advantage is an assessed lower iLUC risk. 
In this context, experiences with incentives for forest plantations are relevant. Many such projects have in common that they would not likely have taken off in the absence of governmental subsidies or tax reductions and in some cases the incentives have resulted in tree planting in areas where soils, rainfall and/or other factors are non-favourable (Evans, 2009). The expansion of willow in Sweden in the 1990s is a case in point; an establishment subsidy for willow and other short rotation crops, in combination with a setaside subsidy to reduce cereal areas, provided a strong incentive for farmers to plant willow. A synthesis of farmer surveys (Dimitrou et al., 2011) provides support for the hypothesis that some farmers established willow plantations largely in response to high investment subsidies, located the plantations on more marginal soils with lower opportunity costs, and employed "low-cost/low-labor" management. Thus, high incentives resulted in rapid expansion but little interest in investments to improve yields. The low yields have in turn resulted in little interest among other farmers and therefore stabilization of the willow area at a low level. In order to avoid similar developments elsewhere, incentive structures need to be designed to promote systems with prospects for becoming costcompetitive in the absence of incentives. Other examples include (i) tax incentives for tree planting in Brazil, where lack of specific priorities for the program led to that plantations were established in remote areas where the likelihood of the plantations being harvested for industrial wood is low (Fégely et al., 2011); and (ii) the Jatropha program in India that was launched to increase domestic bio-diesel production, where poor planning and implementation of the program led to massive fallout among farmers who started Jatropha production (Axelsson et al., 2012).

\section{Conclusions}

Farmers can make very different decisions when engaging with sugarcane, both concerning their land use allocation and their investment in intensification. This makes it challenging to design schemes for promoting iLUC-free biofuels as a means to achieve large GHG emissions reduction in the transport sector. Biofuels production may result in either positive or negative iLUC depending on the details of what happens, but how the production gets assessed with respect to iLUC depends on the criteria used (e.g., the system boundaries and regional vs individual assessment). We have derived hypotheses (see Section 4), both to help understand farmers' actions and opinions in conjunction with shifting to sugarcane and to highlight and elucidate the difficulties in setting criteria for iLUC-free biofuels. It is proposed that these hypotheses be evaluated by surveys or applied in, e.g., agent based models to simulate the behavior of actors with respect to land use and socio-economics. It is likely important to perform studies similar to the one reported here, but in other countries and also relating to other feedstock systems, e.g., tree plantations and integrated systems producing multiple outputs. Further results from such approaches could then help to design low-iLUC schemes in case this approach to addressing concerns about indirect effects is requested.

\section{Acknowledgements}

Financial support from the Anna Whitlock scholarship, B4Energy, and the Swedish Energy Agency; scientific and language support from Paulina Essunger, Hanna Ljungstedt, Johanna Mossberg, Martin Sjödin, and Stefan Wirsenius; interview support, José Eduardo Guercio.

\section{References}

ABC, 2012. Sector Plan for Mitigation and Adaptation to Climate Change for the Consolidation of Economy of Low Carbon in Agriculture (in Portuguese).
Agroconsult, 2014. Rally da pecuaria, third edition (in Portuguese, accessed 20.05.15.) http://www.rallydapecuaria.com.br/downloads.

Anon, 2016. Gasoline Prices Kept Low (accessed 4.07.15.) http://www.reuters.com/ article/2014/08/12/us-brazil-economy-gasoline-exclusiveidUSKBNOGB26920140812.

Axelsson, L., Franzén, M., Ostwald, M., Berndes, G., Lakshmi, G., Ravindranath, N., 2012. Jatropha cultivation in southern India: assessing farmers' experiences. Biofuels Bioprod. Biorefin. 6, 246-256.

Berndes, G., Börjesson, P., Ostwald, M., Palm, M., 2008. Multifunctional biomass production systems - an introduction with presentation of specific applications in India and Sweden. Biofuels, Bioprod. Biorefin. 2, 16-25.

Broch, A., Hoekman, K., Unnasch, S., 2013. A review of variability in indirect land use change assessment and modeling in biofuel policy. Environ. Sci. Policy 29, $147-157$.

California (Environmental Protection Agency - Air Resource Board, 2009. Detailed California-Modified GREET Pathways for Brazilian Sugarcane Ethanol: Average Brazilian Ethanol, With Mechanized Harvesting and Electricity Co-product Credit, With Electricity Co-product Credit. The board: Version 2.3.

Dale, B., Bals, D., Kim, S., Eranki, P., 2010. Biofuels done right: land efficient animal feeds enable large environmental and energy benefits. Environ. Sci. Technol. 44, 8385-8389.

Dale, V., Kline, K., Wright, L., Perlack, R., Downing, M., Graham, R., 2011. Interactions among bioenergy feedstock choices, landscape dynamics, and land use. Ecol. Appl. 21, 1039-1054.

Dimitrou, I., Rosenqvist, H., Berndes, G., 2011. Slow expansion and low yields of willow short rotation coppice in Sweden; implications for future strategies. Biomass Bioenergy 35, 4613-4618.

Egeskog, A., Berndes, G., Freitas, F., Gustafsson, S., Sparovek, G., 2011. Integrating bioenergy and food production - a case study of combined ethanol and dairy production in Pontal, Brazil. Energy Sustain. Dev. 5, 8-16.

Egeskog, A., Freitas, F., Berndes, G., Sparovek, G., Wirsenius, S., 2014. Greenhouse gas balances and land use changes associated with the planned expansion (to 2020) of the sugarcane ethanol industry in Sao Paulo, Brazil. Biomass Bioenergy 63, 280-290.

Embassy of Brazil, 2010. Brazil's Nationally Appropriate Mitigation Actions (accessed 17.06.15.) http://unfccc.int/files/meetings/cop_15/copenhagen. accord/application/pdf/brazilcphaccord_app2.pdf.

European Parliament legislative resolution of 28 April 2015 on the Council position at first reading with a view to the adoption of a directive of the European Parliament and of the Council amending Directive 98/70/EC relating to the quality of petrol and diesel fuels and amending Directive 2009/28/EC on the promotion of the use of energy from renewable sources $(10710 / 2 / 2014$ C8-0004/2015-2012/0288(COD)) (2015).

Evans, J., 2009. Planted Forests; Uses, Impacts and Sustainability. FAO, ISBN: 97892 51062227.

Fégely, R., Stephens, M., Hansard, A., 2011. Review of Policies and Investment Models to Support Continued Plantation Investments in Australia. Forest \& Wood Products Australia, ISBN: 978-1-921763-13-7.

Field, C., Campbell, E., Lobell, D., 2008. Biomass energy: the scale of the potential resource. Trends Ecol. Evol. 23, 65-72.

Filho, J., Horridge, M., 2014. Ethanol expansion and indirect land use change in Brazil. Land Use Policy 36, 595-604.

Francis, G., Edinger, R., Becker, K., 2005. A concept for simultaneous wasteland reclamation, fuel production, and socio-economic development in degraded areas in India: need, potential and perspectives of Jatropha plantations. Nat. Resour. Forum 29, 12-24

Galdos, M., Cavalett, O., Seabra, J., Norgueira, L., Bonomi, A., 2013. Trends in global warming and human health impacts related to Brazilian sugarcane ethanol production considering black carbon emissions. Appl. Energ. 104, 576-582.

Garg, K., Karlberg, L., Wani, S., Berndes, G., 2011. Biofuel production on wastelands in India: opportunities and trade-offs for soil and water management at the watershed scale. Biofuels Bioprod. Biorefin. 5, 410-430.

Gesch, R.W., Archer, D.W., 2013. Double-cropping with winter camelina in the northern Corn Belt to produce fuel and food. Ind. Crops Prod. 44, 718-725.

Heggenstaller, A., Anex, R., Liebman, M., Sundberg, D., Gibson, L., 2008. Productivity and nutrient dynamics in bioenergy double-cropping systems. Agron. J. 100, $1740-1748$

IBGE SIDRA, 2013. Open Database (in Portuguese, accessed 12.06.15.) http://www. sidra.ibge.gov.br.

Kvale, S., 1997. The Qualitative Research Interview. Studentlitteratur, Lund (in Swedish).

Langeveld, A., Dixon, J., van Keulen, H., Quist-Wessel, F., 2014. Analyzing the effect of biofuel expansion on land use in major producing countries: evidence of increased multiple cropping. Biofuels Bioprod. Biorefin. 8, 49-58.

Lapola, D.M., Schaldach, R., Alcamo, J., Bondeau, A., Koch, J., Koelking, C., et al., 2010. Indirect land-use changes can overcome carbon savings from biofuels in Brazil. PNAS 107, 3388-3393.

Law $\mathrm{Nr}$ 12.651, Lei n(12.651, de 25 de maio de, 2012. http://www.planalto.gov.br/ ccivil_03/_ato2011-2014/2012/lei/112651.htm (in Portuguese, accessed 12.06.13.).

Leal, M.R., Horta Nogueira, L.A., Cortez, L.A., 2013. Land demand for ethanol production. Appl. Energy 102, 266-271.

Macedo, I., Seabra, E., Silva, J., 2008. Green house gas emissions in the production and use of ethanol from sugarcane in Brazil: the 2005/2006 averages and a prediction for 2020. Biomass Bioenergy 32, 582-595. 
Macedo, et al., 2014. Greenhouse gas emissions from bioenergy. In: Souza, G., et al. (Eds.), Bioenergy and Sustainability: Bridging the Gaps. Report commissioned by SCOPE-Scientific Committee on Problems of the Environment.

Ministerio Público, 2012. A juíza federal daniela paulovich de lima, da $2 \stackrel{a}{a}$ vara em piracicaba/sp ministério público federal procuradoria da república no município de piracicaba.

Novo, A., Jansen, K., Slingerland, M., Giller, K., 2010. Biofuel, daily production and beef in Brazil: competing claims on land use in São Paulo state. J. Peasant Stud. 37, 769-792

Novo, A., Jansen, K., Slingerland, M., 2012. The sugarcane-biofuel expansion and dairy farmers' responses in Brazil. J. Rural Stud. 28, 640-649.

Peres, A., 2003. Oarrendamento de terras na pequena propriedade fundiaria canavieira: o caso do municipio de piracicaba-SP (Master Thesis) (in Portuguese) http://www.bibliotecadigital.unicamp.br/document/ ?code $=$ vtls000295529\&opt $=4>$.

President of the Republic of Brazil, 2008. National plan on climate change, Brazil. Brasília, LUIZ INÁCIO LULA DA SILVA President of the Federative Republic of Brazil, 2008 (28 pp).RSB, 2015. Round Table on Sustainable Biomaterials. New RSB Standard for Low iLUC Biofuels (accessed 20.05.15.) http://biofuels-news. com/display_news/9190/new_rsb_standard_for_low_iluc_biofuels/.
Sparovek, G., Berndes, G., Egeskog, A., Luiz Mazzaro de Freitas, F., Gustafsson, S., Hansson, J., 2007. Sugarcane ethanol production in Brazil: an expansion model sensitive to socioeconomic and environmental concerns. Biofuels, Bioprod. Biorefin. 1, 270-282.

Terci, E.T., Peres, A.M., Peres, M.T., Guedes, S.N., Shikida, P.F., Corrêa, A.M., 2007. Os mercados de terra e trabalho na (re)estruturação da categoria social dos fornecedores de cana do Estado de São Paulo: análise de dados de campo. Rev. Desenvolvimento Region. 12, 142-167 (in Portuguese).

UNICA, 2015. Brazilian Sugarcane Industry Association (accessed 19.03.15.) http:// www.unica.com.br/in-the-media/414848292034098932/brazilian-governorsjoin-to-halt-crisis-in-sugarcane-and-ethanol-sector/.

USEPA, 2010. Renewable Fuel Standard Program (RFS2) Regulatory Impact Analysis. EPA-420-R-10-006. U.S. EPA (accessed 20.11.12.) http://www.epa. gov/otaq/renewablefuels/420r10006.pdf.

Verstegen J., Hilst F., Wolther G., Karssenberg D., de Jong S., Faaij A., 2015. What can and can't we say about indirect land use change in Brazil using an integrated economic -land use change model? doi:10.1111/gcbb.12270.

Low Indirect Impact Biofuel methodology -version Zero. Authors: Ecofys: Jasper van de Staaij, Daan Peters, Bart Dehue, Sebastian Meyer, Vivian Schueler, Gemma Toop; RSB Secretariat at EPFL: Victoria Junquera; WWF International: Laszlo Mathe (2012). 